\title{
Informing Canada's Health System Response to COVID-19: Priorities for Health Services and Policy Research
}

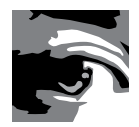 \\ MEGHAN MCMAHON, PHD, MSC \\ Associate Director \\ CIHR Institute of Health Services and Policy Research \\ Toronto, ON \\ JESSICA NADIGEL, PHD \\ Associate Director \\ CIHR Institute of Health Services and Policy Research \\ Montreal, QC \\ ERIN THOMPSON, MPH \\ Project Officer \\ CIHR Institute of Health Services and Policy Research \\ Toronto, ON \\ RICHARD H. GLAZIER, MD, MPH \\ Scientific Director \\ CIHR Institute of Health Services and Policy Research \\ Senior Scientist \\ ICES (Institute for Clinical Evaluative Sciences) \\ Research Scientist \\ MAP Centre for Urban Health Solutions \\ St. Michael's Hospital \\ Professor \\ Family and Community Medicine \\ University of Toronto \\ Toronto, ON
}




\begin{abstract}
To inform Canada's research response to COVID-19, the Canadian Institutes of Health Research's Institute of Health Services and Policy Research (IHSPR) conducted a rapidcycle priority identification process. Seven COVID-19 priorities for health services and policy research were identified: system adaptation and organization of care; resource allocation decision-making and ethics; rapid synthesis and comparative policy analysis of the COVID-19 response and outcomes; healthcare workforce; virtual care; long-term consequences of the pandemic; and public and patient engagement. Three additional cross-cutting themes were identified: supporting the health of Indigenous Peoples and vulnerable populations, data and digital infrastructure, and learning health systems and knowledge platforms. IHSPR hopes these research priorities will contribute to the broader ecosystem for collective research investment and action.
\end{abstract}

\title{
Background
}

The coronavirus disease 2019 (COVID-19) pandemic has had devastating consequences worldwide and revealed the underpreparedness of systems (health, political, economic) to respond swiftly. Health systems are grappling with how to rapidly mobilize, organize and deploy resources to provide effective COVID-19 care while simultaneously attempting to reorganize the provision of non-COVID-19 care effectively and safely. The Government of Canada's top priority throughout the pandemic has been to keep Canadians healthy and safe (Government of Canada 2020), and one mechanism to achieve this has been to mobilize Canada's health research community to respond to the COVID-19 crisis.

As Canada's federal health research funder, the Canadian Institutes of Health Research (CIHR) has played an active role in the COVID-19 health research response along with its tri-council partners, Canada's broader health and science portfolios, provincial and territorial research funders and health systems, charities and hospitals, as well as local, academic, private sector and other funders. On February 10, 2020, CIHR, together with funding partners, launched its first rapid research response funding opportunity (CIHR 2020a), which resulted in 99 funded research projects totalling $\$ 54.2$ million (CIHR 2020b). The Government of Canada then allocated an additional \$115 million to CIHR in March for a second round of rapid research funding (CIHR 2020c). Beyond these, CIHR has led several other COVID-19 funding calls, including the COVID-19 Clinical Epidemiology Research Rapid Response, World Health Organization Solidarity Trial and opportunities focused on mental health and substance use. Additional investments are under way to further support research teams with expiring grants, to maintain income support for trainees whose research has been delayed by the pandemic and to support the retention of research staff at universities and health research institutes.

The CIHR's Institute of Health Services and Policy Research (IHSPR) is one of 13 virtual institutes and one of many players in the health research ecosystem. IHSPR is aiming to create a shared understanding of health services and policy research (HSPR) COVID-19 
priorities across the country to help align resources with the most important evidence needs for policies and interventions that contribute to improved health and health system outcomes. IHSPR identified COVID-19 priorities for HSPR through a rapid and iterative process that included literature and media scans, an environmental scan of COVID-19 research priorities in other countries (Table 1), input from leading HSPR experts in Canada and a brief survey of the HSPR community. Data from these sources were triangulated, analyzed and summarized to distill core and cross-cutting HSPR COVID-19 priorities and validated with the Institute Advisory Board. Detailed methods are available in Appendix 1.

\section{COVID-19 Health Services and Policy Research Priorities}

IHSPR's rapid-cycle priority identification process resulted in seven core priority areas and three cross-cutting themes relevant for research and policy analysis within and across each priority.

\section{System adaptation and organization of care}

Research that informs system adaptation and organization of resources and care in the COVID-19 era is urgently needed as many sectors have been ill-equipped to meet COVID19 care needs, with community care homes (including long-term care [LTC] homes) being hardest hit. Areas of focus include hospitals and the primary, home and community care (including LTC) sectors (Basky 2020; Cadogan and Hughes 2020; Coccolin et al. 2020; Glauser 2020; Grabowski and Joynt Maddox 2020; Lin et al. 2020). Predictive and optimization modelling is needed to inform system resilience, resource planning, disease testing and surveillance systems, patient flow and continuity of care. Also critically needed is research that both evaluates innovations in the organization and delivery of care that were catalyzed as a result of the COVID-19 pandemic, and analyzes the policy options and levers that would support the scale and spread of these innovations.

\section{Resource allocation decision-making and ethics}

COVID-19 has revealed shortages of capacity and resources, including personal protective equipment (PPE) and, in some settings, intensive care unit (ICU) beds and ventilators (Emanuel et al. 2020; Gostin et al. 2020; Phua et al. 2020; Ranney et al. 2020; Truog et al. 2020; Wang et al. 2020). Non-urgent surgeries have been cancelled, and as reopening commences, decisions will be made about prioritization for care. Research, policy analyses and ethical frameworks are required to inform allocative decision-making and the consequences of those decisions (Antommaria et al. 2020; Emanuel et al. 2020; Fritz et al. 2020; Gostin et al. 2020; Rosenbaum 2020a). Further analyses are needed to examine the ethical implications of restrictive public health and social distancing measures, use of technology and data for contact tracing and the equity consequences for vulnerable populations (Laupacis 2020; Mazumder et al. 2020; Mulligan et al. 2020; Smith and Judd 2020; Van Dorn et al. 2020; Wang and Tang 2020). 
Rapid synthesis and comparative policy analysis of the COVID-19 response and outcomes There has been considerable heterogeneity across countries and Canadian jurisdictions in the response and timing of policies enacted to flatten the curve (e.g., social distancing, school closures) and reopen society (e.g., non-essential services, return to school). Rapid knowledge syntheses and comparative policy analyses are needed to document and understand responses, analyze their intended and unintended consequences and develop response options to inform future planning and preparedness. As COVID-19-related policies have been enacted at municipal, provincial/territorial and federal levels and implemented by systems, organizations and individuals, analyses will require appropriate targeting to reach policy and decision-makers with differing mandates, accountabilities and contexts (Gibney 2020).

\section{Healthcare workforce}

The healthcare workforce has needed to adapt quickly to the COVID-19 landscape. Enormous pressure due to a lack of PPE, high workloads and safety concerns (Xiong and Peng 2020) has added considerable stress to healthcare workers (Greenberg 2020; Zhou et al. 2020), many of whom had high levels of burnout prior to the pandemic (Canadian Medical Association 2019). Research is needed to analyze how the healthcare workforce was deployed and supported to provide COVID-19 care, understand the facilitators and barriers to a coordinated and effective response (Basky 2020; Coccolin et al. 2020; Fraher et al. 2020; Lake 2020), evaluate the impacts on COVID-19 and non-COVID-19 care, and consider the strategies and policies that could be implemented to improve workforce planning, capacity and safety. Research is also needed to understand the role that family and other informal caregivers played, the supports and resources they used and/or needed, the impact that COVID-19 had on their health and mental health and the policy options for supporting informal caregivers in the future.

\section{Virtual care}

COVID-19 crystallizes the importance of virtual care to meet patient needs and reduce the risk of disease transmission (Bhatia et al. 2020; Greenhalgh et al. 2020; Hollander and Carr 2020; Smith et al. 2020; Webster 2020). Research is needed to analyze and compare the extent and type of virtual care used across jurisdictions, who provided and received virtual care and for what purpose, the payment policies implemented and the intended and unintended consequences of expanded use. As well, research that analyzes the impact of virtual care on key outcome measures such as access, utilization, continuity, quality and safety, equity, cost and health is important to inform the design of future virtual care models.

\section{Long-term consequences of the COVID-19 pandemic}

To respond to COVID-19, healthcare resources were rapidly redeployed, reducing access to routine and ongoing care and leaving many with cancelled referrals, tests and procedures (Angelico et al. 2020; Carter et al. 2020; Rosenbaum 2020b; Salako et al. 2020). Due to 
fear of infection, many Canadians did not seek healthcare even when needed. Certain sectors, such as LTC, and certain populations, such as the homeless and incarcerated, were disproportionately impacted. Gendered consequences include balancing work, childcare and household duties, which fall disproportionately on women (Kitchener 2020; Minello 2020). Longitudinal research is needed to study the long-term and far-reaching effects of the pandemic on health, health equity and health system outcomes, as well as the post-COVID-19 health, social and economic policies that are created. Policy analysis is imperative to shed light on why the consequences emerged, why they had a disproportionate impact across sectors and populations and to inform future policy development.

\section{Public and patient engagement}

Citizen response to public health advice and restrictions has profound effects on viral transmission and therefore the COVID-19 pandemic itself. Research and policy need to meaningfully engage with the public and patients, including vulnerable and at-risk populations. Priorities need to be established through understanding the experience and perspectives of the public and patients with the pandemic, the COVID-19 and non-COVID-19 care received (or not received), caregiver needs and supports and the supports and tools needed as the crisis subsides (e.g., mental health supports and spiritual care). Public and patient engagement is also critical for decision-making about removing restrictions and what the "return to the new normal" should look like (Immonen 2020).

\section{Cross-cutting themes}

Through IHSPR's rapid-cycle priority identification process, three cross-cutting themes were identified that intersect each of the seven priority areas:

1. Supporting the health of Indigenous Peoples and vulnerable populations: First Nations, Inuit and Métis populations are at high risk of COVID-19 acquisition and severe disease in both rural/remote and urban settings. People who are homeless, incarcerated and living in poverty are also at high risk. HSPR is needed to analyze the impacts of COVID-19 on Indigenous Peoples and vulnerable populations and the factors that exacerbated those impacts. Policy research is also needed to inform the development of post-pandemic health and healthcare policies that are culturally safe and grounded in Indigenous Knowledges.

2. Data and digital infrastructure: COVID-19 has highlighted the importance of timely access to data for researchers, decision-makers and front-line providers to inform policy and care delivery decisions. Access for researchers to linkable data from diverse sources (e.g., COVID-19 testing data linked with clinical and administrative data, consumer wearables, social media and patient reports) and digital infrastructure is needed to enable rapid analysis of the impacts and evidence-informed response strategies. COVID-19 has also revealed critical gaps in data. For example, the lack of race and ethnicity data, 
and measures and data about racism, hinders researchers' ability to decipher differential impacts of the pandemic and inform targeted policy responses, which risks further exacerbating existing inequities in health and outcomes.

3. Learning health systems and knowledge platforms: Knowledge platforms are needed that provide seamless and rapid access to high-quality research studies, synthesize the volumes of research that COVID-19 has spurred and tailor the evidence in ways that meet the diverse needs of policy and decision-makers. COVID-19 illuminates the ability of healthcare delivery systems (e.g., a health authority) and organizations (e.g., a hospital or LTC home) to use COVID-19 and other data to support real-time decision-making, foster continuous learning and evidence-informed planning and implement policies and interventions across the system.

\section{Discussion and Conclusion}

IHSPR is one of many organizations in a broader ecosystem that funds research and is dedicated to contributing to the COVID-19 research response. The priorities identified in this paper are intended to help align collective HSPR investment, activity and collaboration in areas where COVID-19 evidence is critically needed and where it has the most potential to improve the lives of people, the health of populations and the performance of healthcare systems.

As shown in Table 1, the seven priorities are not unique to the Canadian context and conform closely with priorities identified in other jurisdictions. Common priorities include: clinical and health system innovations in the delivery, management and organization of care; deployment of the healthcare workforce and addressing workforce needs; access to care by vulnerable populations; digital health and technological innovations; addressing mental health needs and challenges; and patient and community engagement. Canada's HSPR community has capacity, expertise and leadership in each of these common priorities. This presents an opportunity for Canadian researchers to leverage the community's strengths to lead or engage in international HSPR collaborations and cross-jurisdictional research.

Who is best poised to conduct the research? The impact of research on the COVID-19 response will be enhanced if the interdisciplinary nature of the HSPR field is harnessed. The health policy and care delivery solutions needed are multifaceted and will need to draw on the interdisciplinary expertise of Canada's health services researchers, epidemiologists, political scientists, economists, lawyers, healthcare providers, embedded scientists, policy and decision-makers and patient partners. Their skills in evaluation, health law and policy analysis, health economics, clinical and health informatics, organization and management of care, implementation science and other domains are critical to generating evidence in the identified priority areas that accounts for the complexity of the context and problem and has the potential for real-world impact.

Who is the COVID-19-related HSPR intended for? Given IHSPR's mandate, the research evidence is intended to inform COVID-19-related policy making within ministries 
of health and professional associations and decision-making within health authorities and healthcare delivery organizations. The goal is to equip health policy and decision-makers with evidence they can use to design and implement effective policies, programs and interventions that improve the organization, delivery and outcomes of healthcare. The CIHR COVID-19 rapid response and mental health knowledge synthesis funding calls included an objective to provide evidence to inform decision-making and the health system response. The calls also ensured that peer review criteria assessed the impact of the research and the quality of the proposed knowledge translation plan, but did not require decision-maker involvement on the research teams (CIHR 2020c; CIHR 2020d). To inform policy and decision-making, effort will be needed once the research is funded to meaningfully engage decision-makers in the work and develop effective knowledge mobilization strategies. IHSPR is committed to this effort.

In addition to relevant research as a lever for change, impact within several of the identified priorities will require the use of legislative, regulatory, funding and other policy levers. For example, addressing the COVID-19 crisis that has played out in Canada's LTC homes (Brown 2020) will require timely and relevant research evidence, plus attention to accreditation, regulation and inspection, staffing levels and working conditions, government funding levels and the expansion of public reporting efforts to include measures such as staffing and ownership type.

Importantly for the HSPR community, these COVID-19 priorities are not intended to serve as the sole focus of IHSPR or CIHR. Although CIHR's Spring 2020 Project Grant competition was delayed until summer 2020 and the institutes' strategic funding initiatives were temporarily put on hold, the CIHR Project Grant budget and the institute's budgets have been preserved, and CIHR's open funding programs have reopened. The time horizon for the reopening of CIHR's strategic funding programs is evolving. There is recognition that although concerted attention and resources were required to enable CIHR's rapid response to the COVID-19 crisis, non-COVID-19-related research cannot stop as a consequence.

Within IHSPR, we are actively engaged in CIHR's broader COVID-19 efforts (including our work to identify HSPR COVID-19 priorities) and will continue to finalize our next five-year strategic plan and initiate planning for large-scale funding programs in areas that align with our institute's mandate. The implications of this for the HSPR community are important: there is space and resources for researchers to lead COVID-19-related research, pivot their existing research to contribute to COVID-19 and/or continue with their core HSPR programs of research.

In the face of a pandemic that has placed tremendous demand on resources and generated a significant human toll, HSPR is critically needed to inform the path forward. Research that evaluates the health system response, analyzes and informs policy options and identifies how to improve the design and delivery of health services is essential for many reasons, including successful navigation out of the current pandemic, improving health 
TABLE 1. Comparison of COVID- 19 health services and policy research (HSPR) priorities

\begin{tabular}{|c|c|}
\hline Organization & HSPR-related research priorities* \\
\hline \multicolumn{2}{|l|}{ Jurisdiction: Canada } \\
\hline $\begin{array}{l}\text { Canadian Institutes of Health } \\
\text { Research (CIHR 2020a, 2020c, } \\
\text { 2020d) }\end{array}$ & $\begin{array}{l}\text { As per Operating Grant: Canadian } 2019 \text { Novel Coronavirus (COVID-19) Rapid Research } \\
\text { Funding Opportunity (January 2020), HSPR-relevant research priorities include: } \\
\text { - Medical countermeasures: } \\
\text { " Clinical management } \\
\text { " Social and policy countermeasures: } \\
\text { As per Operating Grant: COVID- } 19 \text { May } 2020 \text { Rapid Research Funding Opportunity, } \\
\text { HSPR-relevant research priorities include: } \\
\text { - Clinical management and health system interventions } \\
\text { - Social, policy and public health responses and related indirect consequences } \\
\text { As per Operating Grant: Knowledge Synthesis: COVID-19 in Mental Health and Substance } \\
\text { Use, HSPR-relevant research priorities include: } \\
\text { - Knowledge translation approaches, practices and platforms applied to inform both } \\
\text { population-level and targeted mental health and substance use responses during the } \\
\text { - Pondemic } \\
\text { impacts of COVID-19 } \\
\text { - Targeted interventions to address the mental health and substance use issues and } \\
\text { needs of high-risk groups } \\
\text { Innovative surveillance and monitoring in both the general Canadian population and } \\
\text { among high-risk groups to assess mental health and substance use needs and system } \\
\text { transformations (including the use of learning health systems, other modes of service } \\
\text { delivery [e.g., virtual care], alternate remuneration models, etc.) }\end{array}$ \\
\hline \multicolumn{2}{|l|}{ Jurisdiction: Global } \\
\hline $\begin{array}{l}\text { World Health Organization } \\
(\mathrm{WHO} 2020)\end{array}$ & \multirow{2}{*}{$\begin{array}{l}\text { As per A Coordinated Global Research Roadmap: } 2019 \text { Novel Coronavirus (March 2020), } \\
\text { HSPR-relevant priorities include: } \\
\text { - Clinical care and health systems } \\
\text { - Engagement } \\
\text { - International coordination }\end{array}$} \\
\hline $\begin{array}{l}\text { World Health Organization/ } \\
\text { Global Research Collaboration } \\
\text { for Infectious Disease } \\
\text { Preparedness (GloPID-R) } \\
\text { (WHO 2020) }\end{array}$ & \\
\hline \multicolumn{2}{|l|}{ Jurisdiction: UK } \\
\hline $\begin{array}{l}\text { National Institute for Health } \\
\text { Research (NIHR) }\end{array}$ & \multirow{2}{*}{$\begin{array}{l}\text { As per the joint NIHR/UKRI COVID- } 19 \text { Rapid Response Rolling Call, HSPR-relevant } \\
\text { research priorities include: } \\
\text { - Health and care delivery } \\
\text { - Clinical management } \\
\text { - Optimized use of personal protective equipment and other infection prevention and } \\
\text { control measures in healthcare and community settings }\end{array}$} \\
\hline $\begin{array}{l}\text { Medical Research Council } \\
\text { (MRC)/UK Research and } \\
\text { Innovation (UKRI) (MRC 2020) }\end{array}$ & \\
\hline \multicolumn{2}{|l|}{ Jurisdiction: US } \\
\hline $\begin{array}{l}\text { AcademyHealth } \\
\text { (AcademyHealth 2020) }\end{array}$ & $\begin{array}{l}\text { As per Health Systems Respond to COVID-19: Priorities for Rapid-Cycle Evaluations } \\
\text { (2020), there are six HSPR-relevant categories of rapid-cycle research and evaluation } \\
\text { priorities: } \\
\text { - Patient and community experience, engagement and outcomes } \\
\text { - Care delivery, management, decision-making and operations } \\
\text { - Workforce needs, training and policies } \\
\text { - Technology, data and telehealth } \\
\text { - Policies, including payment policy } \\
\text { - Collaboration and coordination }\end{array}$ \\
\hline
\end{tabular}




\begin{tabular}{|c|c|}
\hline Organization & HSPR-related research priorities* \\
\hline \multicolumn{2}{|l|}{ Jurisdiction: US (continued) } \\
\hline $\begin{array}{l}\text { Agency for Healthcare Research } \\
\text { and Quality (AHRQ 2020) }\end{array}$ & $\begin{array}{l}\text { As per AHRQ's Novel, High-Impact Studies Evaluating Health System and Healthcare } \\
\text { Professional Responsiveness to COVID-I9 (ROI), HSPR-relevant research topics include: } \\
\text { - Research to improve the quality of care received and patient outcomes during and } \\
\text { following the COVID-19 pandemic } \\
\text { - Research to improve healthcare patient safety during and following the COVID-I9 } \\
\text { pandemic } \\
\text { - Research to understand how the response to COVID-19 affected socially vulnerable } \\
\text { populations and people with multiple chronic conditions during and following the } \\
\text { COVID- I9 pandemic } \\
\text { - Research to understand how digital healthcare innovations contributed to the health } \\
\text { - Rystem response to COVID-19, outcomes and unintended consequences }\end{array}$ \\
\hline $\begin{array}{l}\text { Patient-Centered Outcomes } \\
\text { Research Institute (PCORI 2020) }\end{array}$ & $\begin{array}{l}\text { PCORI's COVID-19-targeted funding opportunity specifies three priority areas: } \\
\text { - Adaptations to healthcare delivery } \\
\text { - Impact of COVID-19 on vulnerable populations } \\
\text { - Impact of COVID-19 on healthcare workforce well-being, management and training }\end{array}$ \\
\hline $\begin{array}{l}\text { National Institutes of Health } \\
(\mathrm{NIH} 2020)\end{array}$ & $\begin{array}{l}\text { As per individual institutes' Notice of Special Interest, examples of HSPR-relevant } \\
\text { research objectives or questions include: } \\
\text { - National Institute on Drug Abuse: how potential overcrowding of emergency } \\
\text { departments and health services will impact the treatment of opioid overdoses and } \\
\text { opioid use disorder } \\
\text { - National Institute on Aging: studies in prehospital, emergency or critical care } \\
\text { settings to improve screening, risk stratification, care delivery decisions, resource } \\
\text { allocation and clinical outcomes for older adults exposed to COVID- I9; evaluating } \\
\text { strategies used by health systems to reallocate resources, rapidly train practitioners, } \\
\text { communicate preventive practices and maintain adherence to public health and } \\
\text { clinical guidelines, with a particular interest in those who serve high-risk groups (e.g., } \\
\text { nursing homes) and resulting racial, ethnic or regional disparities in access/care } \\
\text { - National Institute of Mental Health: studies on the impact (e.g., access, quality, and } \\
\text { clinical outcomes) of state, local, federal and guild-specific guidelines and policies } \\
\text { around telehealth services and of changes in those policies, with specific attention on } \\
\text { the risks and benefits of relaxing those guidelines or policies } \\
\text { - National Institute on Minority Health and Health Disparities: examine the effects of } \\
\text { the COVID- I9 outbreak on disparities in healthcare utilization and health outcomes } \\
\text { among medically and socially vulnerable populations } \\
\text { - National Cancer Institute: impact on cancer-related care delivery due to the COVID- } \\
\text { I9 pandemic } \\
\text { - National Institute of Biomedical Imaging and Bioengineering: the NIBIB is } \\
\text { seeking applications to develop life-saving technologies that can be ready for } \\
\text { commercialization within one to two years; for example: rapid point-of-care and } \\
\text { home-based testing/diagnostics; digital health platforms and models that integrate } \\
\text { data, assess risk and provide illness surveillance and management tools } \\
\text { National Institute on Alcohol Abuse and Alcoholism: what workforce development } \\
\text { and deployment strategies are needed to address emerging challenges in mental } \\
\text { health/alcohol use disorder treatment during the pandemic? }\end{array}$ \\
\hline
\end{tabular}

*Not exhaustive; intended to be a snapshot only.

system preparedness for future outbreaks and ensuring that the Canadian healthcare system that reopens is stronger, resilient, and more accessible, more equitable and of higher quality than the one that existed before the onslaught of COVID-19. 


\section{Acknowledgements}

The authors would like to thank Emma Kaplan, IHSPR Communications and Events Officer, for her help with the media scan that informed this paper. The authors would also like to thank the members of the IHSPR Institute Advisory Board for their insightful and invaluable contributions, comments and feedback regarding the priorities.

Correspondence may be directed to: Meghan McMahon, CIHR-IHSPR at ICES, G1 06, 2075 Bayview Avenue, Toronto, ON M4N 3M5. She can be reached by e-mail at mmcmahon.ibspr@ices.on.ca.

\section{References}

AcademyHealth. 2020. Health Systems Respond to COVID-19: Priorities for Rapid-Cycle Evaluations. Retrieved May 14, 2020. <https://www.academyhealth.org/sites/default/files/healthsystemsrespondtocovid_april2020. $\operatorname{pdf}>$.

Agency for Healthcare Research and Quality (AHRQ). 2020. Novel, High-Impact Studies Evaluating Health System and Healthcare Professional Responsiveness to COVID-19 (R01). Retrieved May 14, 2020. <https:/grants.nih.gov/grants/guide/rfa-files/RFA-HS-20-003.html>.

Angelico, R., S. Trapani, T.M. Manzia, L. Lombardini, G. Tisone and M. Cardiloo. 2020. The COVID19 Outbreak in Italy: Initial Implications for Organ Transplantation Programs. American Journal of Transplantation. doi:10.1111/ajt.15904.

Antommaria, A.H.M., T.S. Gibb, A.L. McGuire, P.R. Wolpe, M.K. Wynia, M.K. Applewhite et al. 2020. Ventilator Triage Policies during the COVID-19 Pandemic at U.S. Hospitals Associated with Members of the Association of Bioethics Program Directors. Annals of Internal Medicine doi:10.7326/M20-1738.

Basky, G. 2020. All Hands on Deck as Cases of COVID-19 Surge. CMAJ 192: E415-16. doi:10.1503/ cmaj.1095859.

Bhatia, R.S., W. Falk, T. Jamieson, C. Piovesan and J. Shaw. 2020, April 7. Virtual Health Care Is Having Its Moment - Rules Will Be Needed [C.D. Howe Institute Intelligence Memo]. Retrieved April 29, 2020. $<$ https://www.cdhowe.org/intelligence-memos/bhatia-falk-jamieson-piovesan-shaw-\%E2\%80\%93-virtualhealthcare-having-its-moment-rules $>$.

Brown, M. 2020, April 22. How COVID-19 Overwhelmed Canada's Long-Term Care System. Folio. Retrieved April 29, 2020. <https://www.folio.ca/how-covid-19-overwhelmed-canadas-long-term-care-system/>.

Cadogan, C.A. and C.M. Hughes. 2020. On the Frontline against COVID-19: Community Pharmacists' Contribution during a Public Health Crisis. Research in Social and Administrative Policy. doi:10.1016/j. sapharm.2020.03.015.

Canadian Institutes of Health Research (CIHR). 2020a. Operating Grant: Canadian 2019 Novel Coronavirus (COVID-19) Rapid Research. Retrieved May 13, 2020. <https://www.researchnet-recherchenet.ca/rnr16/ viewOpportunityDetails.do?prog=3248\&language $=\mathrm{E}>$.

Canadian Institutes of Health Research (CIHR). 2020b. Canadian 2019 Novel Coronavirus (COVID-19) Rapid Research Funding Opportunity Results. Retrieved May 13, 2020. <https://cihr-irsc.gc.ca/e/51908.html>. Canadian Institutes of Health Research (CIHR). 2020c. Operating Grant: COVID-19 May 2020 Rapid Research Funding Opportunity. Retrieved May 13, 2020. <https://www.researchnet-recherchenet.ca/rnr16/ vwOpprtntyDtls.do?prog=3309\&view $=$ currentOpps\&type $=$ EXACT\&resultCount $=25 \&$ sort $=$ program $\&$ next $=$ $1 \&$ all $=1 \&$ masterList $=$ true $>$.

Canadian Institutes of Health Research (CIHR). 2020d. Operating Grant: Knowledge Synthesis: COVID-19 in Mental Health and Substance Use. Retrieved May 13, 2020. <https://www.researchnet-recherchenet.ca/ rnr16/vwOpprtntyDtls,do?prog=3330\&view $=$ currentOpps\&type $=$ EXACT\&resultCount $=25 \&$ sort $=$ program \&next $=1 \&$ all $=1 \&$ masterList $=$ true $>$. 


\section{Informing Canada's Health System Response to COVID-19}

Canadian Medical Association. 2019, October. Physician Health and Wellness in Canada: Connecting Behaviours and Occupational Stressors to Psychological Outcomes. Retrieved May 12, 2020. <https:/www.cma.ca/sites/ default/files/pdf/Media-Releases/NPHS_Report_ENG_Final.pdf>.

Carter, P., M. Anderson and E. Mossialos. 2020. Health System, Public Health, and Economic Implications of Managing COVID-19 from a Cardiovascular Perspective. European Heart Journal. doi:10.1093/eurheartj/ ehaa342.

Coccolin, F., G. Perrone, M. Chiarugi, F.D. Marzo, L. Ansaloni, I. Scandroglio et al. 2020. Surgery in COVID-19 Patients: Operational Directives. World Journal of Emergency Surgery 15: 25. doi:10.1186/ s13017-020-00307-2.

Emanuel, E.J., G. Persad, R. Upshur, B. Thorne, M. Parker, A. Glickman et al. 2020. Fair Allocation of Scarce Medical Resources in the Time of Covid-19. New England Journal of Medicine. doi:10.1056/NEJMsb2005114.

Fraher, E.P., P. Pittman, B.K. Frogner, J. Spetz, J. Moore, A.J. Beck et al. 2020. Ensuring and Sustaining a Pandemic Workforce. New England Journal of Medicine. doi:10.1056/NEJMp2006376.

Fritz, Z., R. Holton and J.P. Fuld. 2020, May 5. Ethical Anchors and Explicit Objectives: Ensuring Optimal Health Outcomes in the Covid-19 Pandemic. BMJ Opinion. Retrieved May 5, 2020. <https://blogs.bmj.com/ bmj/2020/05/05/ethical-anchors-and-explicit-objectives-ensuring-optimal-health-outcomes-in-the-covid-19pandemic/>.

Gibney, E. 2020, April 27. Whose Coronavirus Strategy Worked Best? Scientists Hunt Most Effective Policies. Nature. Retrieved April 29, 2020. <https://www.nature.com/articles/d41586-020-01248-1>.

Glauser, W. 2020. Proposed Protocol to Keep COVID-19 Out of Hospitals. CMAJ 192(10): E264-65. doi:10.1503/cmaj.1095852.

Gostin, L.O., E.A. Friedman and S.A. Wetter. 2020. Responding to Covid-19: How to Navigate a Public Health Emergency Legally and Ethically. Hastings Center Report. doi:10.1002/hast.1090.

Government of Canada. 2020. Government of Canada's Research Response to COVID-19. Retrieved May 13, 2020. <https://www.canada.ca/content/dam/phac-aspc/documents/services/publications/diseases-conditions/ coronavirus/covid-19-government-canada-research-response/covid-19-research-response-eng.pdf $>$.

Grabowski, D.C. and K.E. Joynt Maddox. 2020, March 25. Postacute Care Preparedness for COVID-19: Thinking Ahead. JAMA. doi:10.1001/jama.2020.4686.

Greenberg, N., M. Docherty, S. Gnanapragasam and S. Wessely. 2020. Managing Mental Health Challenges Faced by Healthcare Workers during Covid-19 Pandemic. BMJ 368: m1211. doi:10.1136/bmj.m1211.

Greenhalgh, T., J. Wherton, S. Shaw and C. Morrison. 2020. Video Consultations for Covid-19. BMJ 368: m998. doi:10.1136/bmj.m998.

Hollander, J.E. and B.G. Carr. 2020. Virtually Perfect? Telemedicine for Covid-19. New England Journal of Medicine. 382: 1679-81. doi:10.1056/NEJMp2003539.

Immonen, K. 2020, March 30. The Views of Patients and the Public Should Be Included in Policy Responses to Covid-19. BMJ Opinion. Retrieved April 28, 2020. <https://blogs.bmj.com/bmj/2020/03/30/the-views-ofpatients-and-the-public-should-be-included-in-policy-responses-to-covid-19/>.

Kitchener, C. 2020, April 24. Women Academics Seem to be Submitting Fewer Papers during Coronavirus. The Lily. Retrieved June 1, 2020. <https://www.thelily.com/women-academics-seem-to-be-submitting-fewerpapers-during-coronavirus-never-seen-anything-like-it-says-one-editor/>.

Lake, E.T. 2020. How Effective Response to COVID-19 Relies on Nursing Research. Research in Nursing E Health 43: 213-14. doi:10.1002/nur.22025.

Laupacis, A. 2020. Working Together to Contain and Manage COVID-19. CMAJ 192: E340-41. doi:10.1503/ cmaj.200428.

Lin, M., A. Beliavsky, K. Katz, J.E. Powis, W. Ng, V. Williams et al. 2020. What Can Early Canadian Experience Screening for COVID-19 Teach Us About How to Prepare for a Pandemic? CMAJ 23(192): E314-18. doi:10.1503/cmaj.200305.

Mazumder, H., M. Hossain and A. Das. 2020. Geriatric Care during Public Health Emergencies: Lessons Learned from Novel Corona Virus Disease (COVID-19) Pandemic. Journal of Gerontological Social Work. 63(4): 257-58. doi:10.1080/01634372.2020.1746723. 
Medical Research Council (MRC). 2020. COVID-19 Rapid Response Rolling Call. Retrieved April 29, 2020. $<$ https://mrc.ukri.org/funding/browse/ukri-nihr-covid-19/ukri-nihr-covid-19-rolling-call/>.

Minello, A. 2020, April 17. The Pandemic and the Female Academic. Nature. Retrieved April 29, 2020. <https://www.nature.com/articles/d41586-020-01135-9>.

Mulligan, K., J. Rayner and O. Nnorom. 2020, April 30. Race-Based Health Data Urgently Needed during the Coronavirus Pandemic. The Conversation. Retrieved May 4, 2020. <https://theconversation.com/ race-based-health-data-urgently-needed-during-the-coronavirus-pandemic-136822>.

National Institutes of Health (NIH). 2020. Coronavirus Disease 2019 (COVID-19): Information for NIH Applicants and Recipients of NIH Funding. Retrieved April 29, 2020. <https://grants.nih.gov/policy/naturaldisasters/corona-virus.htm>.

Patient-Centered Outcomes Research Institute (PCORI). 2020. COVID-19 Targeted PFA. Retrieved May 5 , 2020. <https://www.pcori.org/funding-opportunities/announcement/covid-19-targeted-pfa>.

Phua, J., L. Weng, L. Ling, M. Egi, C.-M. Lim, J.V. Divatia et al. 2020. Intensive Care Management of Coronavirus Disease 2019 (COVID-19): Challenges and Recommendations. The Lancet Respiratory Medicine. doi:10.1016/S2213-2600(20)30161-2.

Ranney, M.L., V. Griffeth and A.K. Jha. 2020. Critical Supply Shortages - The Need for Ventilators and Personal Protective Equipment during the Covid-19 Pandemic. New England Journal of Medicine. doi:10.1056/ NEJMp2006141.

Rosenbaum, L. 2020a. Facing Covid-19 in Italy - Ethics, Logistics, and Therapeutics on the Epidemic's Front Line. New England Journal of Medicine. doi:10.1056/NEJMp2005492.

Rosenbaum, L. 2020b. The Untold Toll - The Pandemic's Effects on Patients without Covid-19. New England Journal of Medicine. doi:10.1056/NEJMms2009984.

Salako, O., K. Okunade, M. Allsop, M. Habeebu, M. Toye, G. Oluyede et al. 2020. Upheaval in Cancer Care during the COVID-19 Outbreak. ecancer 14: ed97. doi:10.3332/ecancer.2020.ed97.

Smith, A.C., E. Thomas, C.L. Snoswell, H. Haydon, A. Mehrotra, J. Clemensen et al. 2020. Telehealth for Global Emergencies: Implications for Coronavirus Disease (COVID-19). Journal of Telemedicine and Telecare. doi:10.1177/1357633X20916567.

Smith, J.A. and J. Judd. 2020. COVID-19: Vulnerability and the Power of Privilege in a Pandemic. Health Promotion Journal of Australia 31(2): 158-60. doi:10.1002/hpja.333.

Truog, R.D., C. Mitchell and G.Q. Daley. 2020. The Toughest Triage - Allocating Ventilators in a Pandemic. New England Journal of Medicine. doi:10.1056/NEJMp2005689.

Van Dorn, A., R.E. Cooney and M.L. Sabin. 2020. COVID-19 Exacerbating Inequalities in the US. The Lancet 395: 1243-44. doi: 10.1016/S0140-6736(20)30893-X.

Wang, X., X. Zhang and J. He. 2020. Challenges to the System of Reserve Medical Supplies for Public Health Emergencies: Reflections on the Outbreak of the Severe Acute Respiratory Syndrome Coronavirus 2 (SARS-

CoV-2) Epidemic in China. BioScience Trends 14(1): 3-8. doi:10.5582/bst.2020.01043.

Wang, Z. and K. Tang. 2020. Combating COVID-19: Health Equity Matters. Nature Medicine 26(4): 458. doi:10.1038/s41591-020-0823-6.

Webster, P. 2020. Canada and COVID-19: Learning from SARS. The Lancet 395(10228): 936-37. doi: 10.1016/S0140-6736(20)30670-X.

World Health Organization (WHO). 2020. A Coordinated Global Research Roadmap: 2019 Novel Coronavirus.

Retrieved April 29, 2020. <https://www.who.int/docs/default-source/coronaviruse/coordinated-global-researchroadmap.pdf?sfvrsn=21b0f5c4_18download=true $>$.

Xiong, Y. and L. Peng. 2020. Focusing on Health-Care Providers' Experiences in the COVID-19 Crisis. The Lancet Global Health. doi:10.1016/S2214-109X(20)30214-X.

Zhou, X., C.L. Snoswell, L.E. Harding, M. Bambling, S. Edirippulige, X. Bai, et al. 2020. The Role of Telehealth in Reducing the Mental Health Burden from COVID-19. Telemedicine and e-Health 26(4): 377-79. doi:10.1089/tmj.2020.0068. 


\title{
Informing Canada's Health System Response to COVID-19: Priorities for Health Services and Policy Research
}

\author{
MEGHAN MCMAHON, JESSICA NADIGEL, ERIN THOMPSON AND RICHARD H. GLAZIER
}

APPENDIX 1. Methods for the rapid-cycle priority identification process

\section{Continuously updated rapid literature scan}

A rapid scan was conducted in late March and updated in late April to identify the range of health services and policy research (HSPR) COVID-19-related research questions and themes emerging in the peer-reviewed literature. MEDLINE and the Cochrane Database of Systematic Reviews were searched in conjunction with selected journal websites, including CMAJ, New England Journal of Medicine, BMJ, BMC Health Services Research and The Lancet. The search included two main concepts: COVID-19 (and its variant terms) and HSPR (and variations including health services research, health policy research and health research). Titles, abstracts and full text were reviewed for relevance to COVID-19-related HSPR priorities.

\section{Media scan}

A rapid scan of national, mainstream media sources was conducted in late March and again in mid-April to identify the nature and breadth of the health services and policy-related COVID-19 issues featured in the news. The Globe and Mail, National Post, CBC and CTV websites and articles written by key Canadian health reporters were scanned.

\section{Input from HSPR experts}

A convenience sample of HSPR experts representing various sectors and expertise was consulted for insight on COVID-19-related HSPR priorities. The sample included the CIHR-IHSPR Institute Advisory Board (IAB) $(n=14)$ (https://cihr-irsc.gc.ca/e/50749. html), leading health services policy researchers and decision-makers $(n=13)$ and executives from Canada's provincial health research funding agencies $(n=9)$. The initial request featured an open-ended question asking for their perspective on top priorities for research investment and attention. Respondents were then sent a draft list of the emerging priorities and invited to comment and refine. The IHSPR IAB met twice (mid-April and early May) to discuss these priorities. 


\section{HSPR community survey}

A brief survey was issued to the HSPR community. The survey focused on two core questions: "What are the most important COVID-19 priorities for HSPR?" and "How has your research been impacted by COVID-19?" These questions were posed through a combination of structured multiple choice and open-ended response options. The survey was distributed through the CIHR-IHSPR listserv and further promoted via Twitter. Overall, 235 survey responses were received and analyzed. The present paper has incorporated results obtained through the priorities question. 


\title{
Éclairer la réponse du système de santé canadien à la COVID-19 : priorités pour la recherche sur les services et les politiques de santé
}

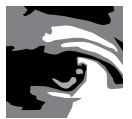 \\ MEGHAN MCMAHON, PhD, MSc \\ Directrice associée \\ Institut des services et des politiques de la santé \\ IRSC \\ Toronto, ON \\ JESSICA NADIGEL, PHD \\ Directrice associée \\ Institut des services et des politiques de la santé \\ IRSC \\ Montréal, QC \\ ERIN THOMPSON, MPH \\ Agente de projet \\ Institut des services et des politiques de la santé \\ IRSC \\ Toronto, ON \\ RICHARD H. GLAZIER, MD, MPH \\ Directeur scientifique \\ Institut des services et des politiques de la santé \\ IRSC \\ Scientifique principal \\ Institut de recherche en services de santé (ICES) \\ Scientifique \\ Centre de solutions en santé urbaine MAP \\ Hôpital St. Michael \\ Professeur, médecine familiale et communautaire \\ Université de Toronto \\ Toronto, ON
}




\section{Résumé}

Afin d'éclairer la réponse du Canada en matière de recherche sur la COVID-19, l'Institut des services et des politiques de la santé (ISPS), des Instituts de recherche en santé du Canada, a mené un processus d'identification rapide des priorités en matière de recherche. Sept priorités ont ainsi été identifiées : adaptation du système et organisation des soins; éthique et prise de décision en matière d'allocation des ressources; synthèses et analyses comparatives rapides des résultats et des politiques d'interventions face à la COVID-19; personnel de la santé; soins virtuels; conséquences à long terme de la pandémie; et engagement de la population et des patients. Trois thèmes transversaux supplémentaires ont été identifiés : soutien à la santé des Peuples Autochtones et des populations vulnérables; données et infrastructures numériques; et systèmes de santé apprenants et plateformes de connaissances. L'ISPS souhaite que ces priorités de recherche contribuent à enrichir l'écosystème de l'investissement et des initiatives de recherche collective.

\section{Contexte}

La pandémie de la maladie à coronavirus 2019 (COVID-19) a des conséquences dévastatrices dans le monde entier et fait voir la sous-préparation des systèmes (sanitaires, politiques, économiques) pour réagir rapidement. Les systèmes de santé cherchent à mobiliser, organiser et déployer rapidement des ressources pour fournir des soins efficaces contre la COVID19 tout en tentant de réorganiser la prestation de soins efficaces et sûrs pour les affections autres que la COVID-19. La principale priorité du gouvernement du Canada pendant la pandémie est d'assurer la santé et la sécurité des Canadiens et des Canadiennes (Government of Canada 2020). Un des mécanismes pour y parvenir consiste à mobiliser le milieu de la recherche en santé pour répondre à la crise de COVID-19.

En tant que bailleur de fonds fédéral pour la recherche en santé au Canada, les Instituts de recherche en santé du Canada (IRSC) jouent un rôle actif dans la réponse de recherche face à la COVID-19, et ce, de concert avec leurs partenaires des trois conseils, les principaux portefeuilles canadiens pour la santé et les sciences, les bailleurs de fonds et les systèmes de santé provinciaux et territoriaux, les organismes de bienfaisance, les hôpitaux ainsi que les bailleurs de fonds locaux, universitaires, du secteur privé et autres. Le 10 février 2020, les IRSC, en collaboration avec d'autres partenaires de financement, ont lancé leur première possibilité de financement pour une intervention de recherche rapide (CIHR 2020a), laquelle a donné lieu au financement de 99 projets de recherche pour un total de 54,2 M\$ (CIHR 2020b). En mars dernier, le gouvernement du Canada allouait 115 M\$ supplémentaires aux IRSC pour une deuxième ronde de financement de recherche rapide (CIHR 2020c). Par ailleurs, les IRSC ont lancé plusieurs autres appels à proposition de financement, notamment l'Intervention de recherche rapide en épidémiologie clinique sur la COVID-19, l'Essai clinique « Solidarity » de traitements contre la COVID-19 de l'Organisation mondiale de la santé ainsi que des possibilités de financement axé sur la santé mentale et la toxicomanie. 
D'autres investissements sont prévus pour soutenir davantage les équipes de recherche dont les subventions arrivent à échéance, pour assurer le revenu des stagiaires dont les projets de recherche sont retardés par la pandémie et pour favoriser la rétention du personnel de recherche dans les universités et les instituts de recherche en santé.

L'Institut des services et des politiques de la santé (ISPS) des IRSC est un des 13 instituts virtuels et un des nombreux acteurs du milieu de la recherche en santé. L'ISPS souhaite déterminer les priorités nationales communes en matière de recherche sur les services et les politiques de santé (RSPS) dans le contexte de la COVID-19 afin d'aligner les ressources pour obtenir les données nécessaires aux politiques et aux interventions qui contribueront à l'amélioration de la santé et des résultats du système de santé. L'ISPS a identifié les priorités de RSPS grâce à un processus rapide et itératif qui comprenait une revue de la littérature et des médias, une analyse des priorités de recherche sur la COVID19 dans d'autres pays (tableau 1), les commentaires d'experts canadiens de la RSPS et une brève enquête auprès du milieu de la RSPS. Les données de ces sources ont été triangulées, analysées et résumées pour en tirer les priorités de RSPS centrales et transversales liées à la COVID-19, lesquelles ont été validées auprès du conseil consultatif de l'Institut. Pour plus de renseignements sur la méthode employée, voir l’annexe 1.

\section{Priorités de recherche sur les services et les politiques de santé dans le contexte de la COVID-19}

Le processus de l'ISPS pour l'identification rapide des priorités a permis de dégager sept domaines prioritaires et trois thèmes transversaux pertinents pour la recherche et l'analyse des politiques parmi lesdits domaines.

\section{Adaptation du système et organisation des soins}

Il est urgent de mener des recherches qui permettent d'éclairer l'adaptation des systèmes et l'organisation des ressources et des soins à l'ère de la COVID-19, car de nombreux secteurs sont mal équipés pour répondre aux besoins en matière de soins pour cette maladie; les foyers de soins communautaires, notamment les foyers de soins de longue durée (SLD), étant les plus durement touchés. Les domaines d'intérêt comprennent les hôpitaux et les secteurs des soins primaires, à domicile et communautaires (y compris les SLD) (Basky 2020; Cadogan et Hughes 2020; Coccolin et al. 2020; Glauser 2020; Grabowski et Joynt Maddox 2020; Lin et al. 2020). Les modèles prédictifs et d'optimisation sont nécessaires pour guider la résilience du système, la planification des ressources, les systèmes de dépistage et de surveillance, le flux des patients et la continuité des soins. Il est également indispensable de mettre en œuvre des recherches pour évaluer les innovations en matière d'organisation et de prestation des soins qui ont été mobilisées en raison de la pandémie. Ces recherches sont aussi indispensables pour analyser les options politiques et les leviers nécessaires à la diffusion à grande échelle des innovations. 


\section{Éthique et prise de décision en matière d'allocation des ressources}

La crise de COVID-19 a révélé des lacunes en matière de capacités et de ressources, notamment en ce qui concerne les équipements de protection individuelle et, dans certains établissements, les lits et les ventilateurs dans les unités de soins intensifs (Emanuel et al. 2020; Gostin et al. 2020; Phua et al. 2020; Ranney et al. 2020; Truog et al. 2020; Wang et al. 2020). Les chirurgies non urgentes ont été annulées et, à mesure que les réouvertures commenceront, des décisions seront prises concernant la hiérarchisation des soins. La recherche, l'analyse des politiques et des cadres éthiques sont nécessaires pour éclairer la prise de décisions concernant l'allocation ainsi que les conséquences de ces décisions (Antommaria et al. 2020; Emanuel et al. 2020; Fritz et al. 2020; Gostin et al. 2020; Rosenbaum 2020a). Des analyses supplémentaires sont nécessaires pour étudier les répercussions éthiques des mesures de santé publique et de distanciation sociale, l'utilisation de la technologie et des données pour la recherche des contacts ainsi que les conséquences d'ordre éthique pour les populations vulnérables (Laupacis 2020; Mazumder et al. 2020; Mulligan et al. 2020; Smith et Judd 2020; Van Dorn et al. 2020; Wang et Tang 2020).

Synthèses et analyses comparatives rapides des résultats et des politiques d'interventions face à la COVID-19

Il y a une hétérogénéité considérable entre les pays ainsi quentre les provinces et territoires du Canada dans la réponse et le calendrier des politiques adoptées pour aplanir la courbe (par exemple, distanciation sociale, fermetures d'écoles) et pour rouvrir la société (par exemple, services non essentiels, retour à l'école). Il faut procéder rapidement à des synthèses des connaissances et à des analyses comparatives des politiques pour documenter et comprendre les interventions, pour analyser leurs conséquences escomptées ou non intentionnelles et pour développer des options d'intervention afin d'éclairer les mesures de planification et de préparation. Étant donné que les politiques publiques liées à la COVID-19 ont été décidées aux niveaux municipal, provincial, territorial et fédéral puis mises en œuvre dans les systèmes, les organisations ou chez les particuliers, ces analyses nécessiteront un ciblage approprié afin d'intéresser les responsables de politiques et les décideurs dont les mandats, les responsabilités et les contextes d'intervention diffèrent grandement (Gibney 2020).

\section{Personnel de la santé}

Le personnel de la santé a dû sadapter rapidement au contexte de la COVID-19. La forte pression due au manque d'équipement de protection individuelle, à la charge de travail élevée et aux problèmes de sécurité (Xiong et Peng 2020) ajoute un stress considérable pour les travailleurs de la santé (Greenberg 2020; Zhou et al.2020), dont plusieurs affichaient déjà un niveau élevé d'épuisement professionnel avant la pandémie (Canadian Medical Association 2019). Des recherches sont nécessaires pour analyser comment le personnel de la santé a été déployé et soutenu dans la prestation de soins pour la COVID-19, pour comprendre les 
facilitateurs et les obstacles à une intervention coordonnée et efficace (Basky 2020; Coccolin et al. 2020; Fraher et al. 2020; Lake 2020), pour évaluer l'impact sur les soins pour la COVID-19 et les autres maladies ainsi que pour examiner les stratégies et politiques qui pourraient être mises en œuvre afin d'améliorer la planification, la capacité et la sécurité de la main-d'œuvre. Des recherches sont également nécessaires pour comprendre le rôle joué par la famille et les autres aidants naturels, pour connaître le soutien et les ressources qu'ils ont utilisés ou dont ils auraient eu besoin, pour évaluer l'impact de la COVID-19 sur leur santé physique et mentale et pour dégager les options politiques visant à soutenir les aidants naturels à l'avenir.

\section{Soins virtuels}

La crise de COVID-19 renforce l'importance des soins virtuels pour répondre aux besoins des patients et réduire le risque de transmission de maladies (Bhatia et al. 2020; Greenhalgh et al. 2020; Hollander et Carr 2020; Smith et al. 2020; Webster 2020). Des recherches sont nécessaires pour analyser et comparer l'étendue et le type de soins virtuels utilisés dans toutes les juridictions, pour savoir qui a fourni des soins virtuels, qui en a reçu et dans quel but, pour étudier les politiques de paiement mises en œuvre et pour dégager les conséquences prévues ou non intentionnelles d'une utilisation accrue des soins virtuels. De plus, il est important d'effectuer des recherches pour analyser l'impact des soins virtuels sur la mesure de résultats clés comme l'accès, l'utilisation, la continuité, la qualité et la sécurité, l'équité, les coûts et la santé, et ce, afin d'éclairer la conception d'éventuels modèles de soins virtuels.

\section{Conséquences à long terme de la pandémie de COVID-19}

Pour faire face à la COVID-19, les ressources des services de santé ont été rapidement redéployées, ce qui a réduit l'accès aux soins de routine et continus et forcé l'annulation de nombre d'aiguillages, d'examens ou de procédures (Angelico et al. 2020; Carter et al. 2020; Rosenbaum 2020b; Salako et al. 2020). En raison d'une crainte de contagion, de nombreux Canadiens et Canadiennes n'ont pas cherché à obtenir les soins de santé dont ils auraient eu besoin. Certains secteurs, comme les SLD, et certaines populations, comme les sansabri et les personnes détenues, ont été touchés de façon disproportionnée. La question de l'équilibre entre le travail, la garde des enfants et les tâches ménagères incombe de manière disproportionnée aux femmes (Kitchener 2020; Minello 2020). Une recherche longitudinale est nécessaire pour étudier les effets à long terme et à grande échelle de la pandémie sur la santé, sur l'équité en santé, sur les résultats du système ainsi que sur les politiques sanitaires, sociales et économiques qui seront élaborées après la pandémie. L'analyse des politiques est impérative pour faire la lumière sur les raisons pour lesquelles ces conséquences sont apparues et pourquoi elles ont eu un impact disproportionné dans certains secteurs et certaines populations, ainsi que pour guider l'élaboration des politiques à venir. 


\section{Engagement de la population et des patients}

La réaction citoyenne face aux conseils et restrictions en matière de santé publique a des effets profonds sur la transmission virale et, par conséquent, sur la pandémie de COVID-19 elle-même. La recherche et les politiques doivent interpeller efficacement la population et les patients, notamment les groupes les plus vulnérables. Il faut établir les priorités en tenant compte : de l'expérience de la population et des patients atteints; des soins, reçus ou non, pour la COVID-19 et les autres affections; de l'appui et des besoins des proches aidants ainsi que du soutien et des outils nécessaires pendant la sortie de la crise (par exemple, soutien en santé mentale et soutien spirituel). L'engagement de la population et des patients est également essentiel pour la prise de décisions concernant la suppression des restrictions et pour avoir une idée des allures que pourrait prendre un « retour à la nouvelle normale » (Immonen 2020).

\section{Thèmes transversaux}

Le processus de l'ISPS pour l'identification rapide des priorités a permis de dégager trois thèmes transversaux qui recoupent chacun des sept domaines prioritaires :

1. Soutenir la santé des Peuples Autochtones et des populations vulnérables. Les populations Premières Nations, Inuits et Métisses courent un risque élevé de contracter la COVID-19 ou des maladies graves, tant dans les milieux urbains que ruraux et éloignés. Le risque est également élevé pour les personnes sans-abris, les détenus et ceux qui sont en situation de pauvreté. La RSPS est nécessaire pour analyser les impacts de la COVID-19 sur les Peuples Autochtones et les populations vulnérables de même que pour connaître les facteurs qui exacerbent la situation. La RSPS est également nécessaire pour éclairer l'élaboration de politiques de santé post-pandémiques qui seront culturellement acceptables et fondées sur le savoir autochtone.

2. Données et infrastructures numériques. La crise de COVID-19 fait voir l'importance d'un accès rapide aux données pour les chercheurs, les décideurs et les fournisseurs de services de première ligne afin d'éclairer les décisions en matière de politiques et de prestation de soins. L'accès à des données contextualisées provenant de diverses sources (par exemple, les données de dépistage de la COVID-19 liées aux données cliniques et administratives, aux dispositifs portables, aux médias sociaux ou aux témoignages des patients) et à une infrastructure numérique est nécessaire pour permettre une analyse rapide de l'impact et des stratégies d'intervention fondées sur les données probantes. La crise de COVID-19 a également révélé de graves lacunes en matière de données. Par exemple, le manque de données sur la race et l'origine ethnique, et mesures et données sur le racisme, entrave la capacité des chercheurs à comprendre les répercussions de la pandémie en fonction des divers groupes et à éclairer les interventions politiques ciblées, ce qui risque d'aggraver encore les inégalités existantes en matière de santé. 
3. Systèmes de santé apprenants et plateformes de connaissances. Les plateformes de connaissances sont nécessaires pour fournir un accès transparent et rapide à des recherches de haute qualité, pour synthétiser le volume des recherches suscitées par la COVID-19 et pour adapter les données probantes de manière à répondre aux divers besoins des décideurs. La pandémie met en évidence la capacité des systèmes de santé (par exemple, une autorité sanitaire) et des organisations (par exemple, un hôpital ou un foyer de SLD) à utiliser les données sur la COVID-19 ainsi que d'autres données pour une prise de décision en temps réel, pour un apprentissage continu et pour la mise en œuvre de politiques et d'interventions éclairées par les données probantes dans l'ensemble du système.

\section{Discussion et conclusion}

L'ISPS est une des nombreuses organisations d'un vaste écosystème qui finance la recherche et qui se consacre à contribuer à la réponse de la recherche face à la COVID-19. Les priorités identifiées dans le présent document visent à aider à aligner l'investissement, les activités et la collaboration dans les domaines où les données probantes sur la COVID-19 sont indispensables et où elles sont le plus susceptibles d'améliorer la vie des gens, la santé des populations et la performance des systèmes de santé.

Comme le montre le tableau 1, les sept priorités ne sont pas propres au contexte canadien et correspondent étroitement aux priorités identifiées dans d'autres pays. Les priorités communes comprennent : les innovations cliniques et du système de santé pour la prestation, la gestion et l'organisation des soins; le déploiement du personnel de la santé et les besoins en main-d'œuvre; l'accès aux soins pour les populations vulnérables; la santé numérique et les innovations technologiques; la réponse aux besoins et aux défis en matière de santé mentale; et l'engagement des patients et des communautés. Au Canada, le milieu de la RSPS a la capacité, l'expertise et le leadership dans chacune de ces priorités communes. C'est l'occasion pour les chercheurs canadiens de tirer parti des forces du milieu de la recherche afin de diriger ou de participer à des collaborations internationales recherches inter-juridictionelle or interterritoriale or inter-gouvernementale.

Qui est le mieux placé pour mener ces recherches? L'impact de la recherche sera renforcé si la nature interdisciplinaire de la RSPS est exploitée. Les solutions en matière de politiques de santé et de prestation des soins sont multiples et devront s'appuyer sur l'expertise interdisciplinaire des chercheurs, épidémiologistes, politologues, économistes, juristes, prestataires de soins de santé, scientifiques, décideurs et patients partenaires. Leurs compétences en évaluation, en droit de la santé, en analyse des politiques, en économie de la santé, en informatique clinique, en organisation et en gestion des soins, en science de la mise en œuvre ou dans d'autres domaines sont essentielles pour générer des données probantes dans les domaines prioritaires identifiés, ce qui rend compte de la complexité du contexte et des problèmes, mais offre aussi le potentiel de résultats concrets. 
À qui sáadresse la RSPS liée à la COVID-19? En raison du mandat de l'ISPS, les résultats de ces recherches viseront à éclairer l'élaboration des politiques au sein des ministères de la santé et des associations professionnelles ainsi que la prise de décisions au sein des autorités sanitaires et des organisations de prestation de soins de santé. L'objectif est de présenter, aux décideurs et aux responsables des politiques de santé, des données probantes qu'ils pourront utiliser pour concevoir et mettre en œuvre des politiques, des programmes et des interventions efficaces pour l'organisation et la prestation des soins de santé. Les appels de financement lancés par les IRSC pour une intervention de recherche rapide contre la COVID-19 et pour la synthèse des connaissances en matière de santé mentale comprenaient chacun l'objectif de fournir des données probantes pour éclairer la prise de décision et la réaction du système de santé ainsi que pour garantir que les critères d'examen par les pairs tiennent compte de l'impact de la recherche et de la qualité du plan proposé pour l'application des connaissances. Il n'y a pas d'exigence quant à la participation de décideurs aux équipes de recherche (CIHR 2020c; CIHR 2020d). Cependant, afin d'éclairer l'élaboration de politiques et la prise de décision, des efforts seront nécessaires pour impliquer de manière significative les décideurs dans le développement de stratégies efficaces pour la mobilisation des connaissances. L'ISPS s'inscrit dans cet effort.

La recherche pertinente peut agir comme agent de changement, mais l'impact de plusieurs des priorités identifiées nécessitera aussi un recours à des leviers législatifs, réglementaires, financiers et autres. Par exemple, pour faire face à la crise de COVID-19 dans les foyers de SLD au Canada (Brown 2020), des données de recherche pertinentes et opportunes seront nécessaires, mais il faudra aussi porter attention à l'accréditation, à la réglementation, à l'inspection, aux niveaux de dotation, aux conditions de travail et aux niveaux de financement du gouvernement. Les rapports publics devraient aussi inclure des mesures telles que la dotation en personnel et le type de propriété.

Le milieu de la RSPS doit savoir que ces priorités de recherche liées à la COVID-19 ne forment pas l'unique centre d'intérêt de l'ISPS ou des IRSC. Bien que le concours des subventions Projet du printemps des IRSC ait été reporté à l'été 2020 et que les initiatives de financement stratégique des instituts aient été temporairement suspendues, le budget des subventions de projet des IRSC ainsi que les budgets des instituts ont été préservés. Par ailleurs, les programmes ouverts de financement des IRSC ont été relancés. L'horizon temporel pour les appels de financement propres à la COVID-19 et pour la réouverture des programmes de financement stratégiques des IRSC est en cours de développement. On reconnaît que même si l'attention et les ressources concertées sont nécessaires pour permettre une réaction rapide des IRSC face à la crise actuelle, la recherche non liée à la COVID-19 ne doit pas pour autant śarrêter.

Même s'il participe activement aux vastes efforts des IRSC face à la COVID-19 (notamment par son travail pour identifier les priorités de RSPS), l'ISPS poursuit la finalisation de son prochain plan stratégique quinquennal ainsi que la planification des programmes de financement à grande échelle dans les domaines qui répondent à son mandat. 
Les conséquences pour le milieu de la RSPS sont importantes : il y a la place et les ressources pour que les chercheurs mènent des recherches liées à la COVID-19, réorientent leurs recherches en cours pour contribuer à l'effort contre la COVID-19 ou poursuivent leurs programmes de recherche de base.

Face à une pandémie qui exerce une forte demande en ressources et qui cause un lourd tribut humain, la RSPS est indispensable pour éclairer la voie à suivre. Il est essentiel de mener des recherches qui évaluent la réaction du système de santé, qui analysent et informent les options politiques et qui trouvent des pistes d'amélioration pour la prestation des services de santé. Cette recherche est essentielle pour de nombreuses raisons, notamment la sortie de la pandémie actuelle, l'amélioration de la préparation du système de santé face à d'éventuelles éclosions et la garantie que le système de santé canadien qui en découle sera plus fort, plus accessible, plus équitable et de meilleure qualité que celui qui existait avant l'assaut de la COVID-19.

\section{Remerciements}

Les auteurs souhaitent remercier Emma Kaplan, IHSPR Communications and Events Officer, pour son aide dans l'analyse des médias pour ce document. Les auteurs tiennent également à remercier les membres du conseil consultatif de l'ISPS pour leurs contributions inestimables et leurs commentaires avisés au sujet des priorités.

Adresse pour correspondance: Meghan McMahon, IRSC-ISPS à l'ICES, G1 06, 2075 Bayview Avenue, Toronto, ON M4N 3M5 ou par courriel à mmomahon.ibspr@ices.on.ca.

\section{Références}

Veuillez vous reporter à la liste dans la version anglaise (p. 11-13). 
TABLEAU 1. Comparaison des priorités en matière de recherche sur les services et les politiques de santé (RSPS) liée à la COVID- 19

\begin{tabular}{|c|c|}
\hline Organisation & Priorités de recherche* \\
\hline \multicolumn{2}{|l|}{ Pays : Canada } \\
\hline $\begin{array}{l}\text { Instituts de recherche en } \\
\text { santé du Canada (CIHR } \\
\text { 2020a, 2020c, 2020d) }\end{array}$ & $\begin{array}{l}\text { Conformément à la Subvention de fonctionnement : Possibilité de financement canadienne pour une intervention } \\
\text { de recherche rapide contre la maladie à coronavirus } 2019 \text { (COVID-19) (janvier 2020), les priorités de } \\
\text { recherche pertinentes portent sur les sujets suivants : } \\
\text { - Contre-mesures médicales : } \\
\text { - Contre-mesures sociales et politiques : } \\
\text { „ Coordination, gouvernance et logistique } \\
\text { Conformément à la Subvention de fonctionnement : Possibilité de financement pour une intervention de } \\
\text { recherche rapide contre la COVID-19 (mai 2020), les priorités de recherche pertinentes portent sur les } \\
\text { sujets suivants: } \\
\text { - Interventions liées à la prise en charge clinique et à la gestion des systèmes de santé } \\
\text { - Interventions sociales, stratégiques et en santé publique, y compris les conséquences indirectes de ces } \\
\text { interventions } \\
\text { Conformément à la Subvention de fonctionnement : Synthèse des connaissances : Santé mentale, toxicomanie } \\
\text { et COVID-19, les priorités de recherche pertinentes portent sur les sujets suivants : } \\
\text { - Approches, pratiques et plateformes d'application des connaissances utilisées pour éclairer les } \\
\text { interventions populationnelles et ciblées en matière de santé mentale et de toxicomanie pendant la } \\
\text { - Interventions à l'échelle des populations visant à réduire les conséquences potentielles de la COVID-19 } \\
\text { sur la santé mentale et la toxicomanie } \\
\text { de santé mentale et de toxicomanie } \\
\text { groupes à risque élevé pour évaluer les besoins en matière de santé mentale et de toxicomanie et } \\
\text { déterminer les transformations systémiques qui s'imposent (systèmes de santé apprenants, autres modes } \\
\text { de prestation de services comme les soins virtuels, différents modèles de rémunération, etc.) }\end{array}$ \\
\hline \multicolumn{2}{|l|}{ Pays : International } \\
\hline $\begin{array}{l}\text { Organisation mondiale de la } \\
\text { Santé (WHO 2020) }\end{array}$ & \multirow{2}{*}{$\begin{array}{l}\text { Conformément à la feuille de route pour la recherche intitulée A Coordinated Global Research Roadmap: } \\
2019 \text { Novel Coronavirus (March 2020), les priorités de recherche pertinentes portent sur les sujets suivants : } \\
\text { - Soins cliniques et systèmes de santé } \\
\text { - Engagement } \\
\text { - Coordination internationale }\end{array}$} \\
\hline $\begin{array}{l}\text { Organisation mondiale de } \\
\text { la Santé / Global Research } \\
\text { Collaboration for Infectious } \\
\text { Disease Preparedness } \\
\text { (GloPID-R) (WHO 2020) }\end{array}$ & \\
\hline \multicolumn{2}{|l|}{ Pays : Royaume-Uni } \\
\hline $\begin{array}{l}\text { National Institute for Health } \\
\text { Research (NIHR) }\end{array}$ & \multirow{2}{*}{$\begin{array}{l}\text { Conformément à l'appel conjoint NIHR/UKRI, intitulé COVID-19 Rapid Response Rolling Call, les priorités de } \\
\text { recherche pertinentes portent sur les sujets suivants : } \\
\text { - Santé et prestation des soins } \\
\text { - Gestion clinique } \\
\text { - Utilisation optimale de l'équipement de protection individuelle et d'autres mesures de prévention et de } \\
\text { contrôle des infections dans les établissements de santé et les milieux communautaires }\end{array}$} \\
\hline $\begin{array}{l}\text { Medical Research Council } \\
\text { (MRC)/UK Research and } \\
\text { Innovation (UKRI) (MRC } \\
\text { 2020) }\end{array}$ & \\
\hline \multicolumn{2}{|l|}{ Pays : États-Unis } \\
\hline $\begin{array}{l}\text { AcademyHealth } \\
\text { (AcademyHealth 2020) }\end{array}$ & $\begin{array}{l}\text { Le document Health Systems Respond to COVID-19: Priorities for Rapid-Cycle Evaluations (2020), présente les } \\
\text { six catégories de priorités de recherche et d'évaluation rapides suivantes : } \\
\text { - Expérience, engagement et résultats des patients et de la communauté } \\
\text { - Prestation de soins, gestion, prise de décisions et opérations } \\
\text { - Besoins en main-d'œuvre, formation du personnel et politiques de travail } \\
\text { - Technologie, données et télésanté } \\
\text { - Politiques, notamment les politiques de paiement } \\
\text { - Collaboration et coordination }\end{array}$ \\
\hline
\end{tabular}




\section{Éclairer la réponse du système de santé canadien à la COVID-19}

\begin{tabular}{|c|c|}
\hline Organisation & Priorités de recherche* \\
\hline \multicolumn{2}{|l|}{ Pays : États-Unis (suite) } \\
\hline $\begin{array}{l}\text { Agency for Healthcare } \\
\text { Research and Quality (AHRQ } \\
\text { 2020) }\end{array}$ & $\begin{array}{l}\text { Conformément à l'annonce de l'AHRQ, Novel, High-Impact Studies Evaluating Health System and Healthcare } \\
\text { Professional Responsiveness to COVID-19 (ROI), les sujets de recherche pertinents comprennent les points } \\
\text { suivants : } \\
\text { - Recherche pour améliorer la qualité des soins reçus et les résultats pour les patients pendant et après la } \\
\text { pandémie de COVID-19 } \\
\text { - Recherche pour améliorer la sécurité des patients pendant et après la pandémie de COVID-19 } \\
\text { - Recherche pour comprendre comment la réponse face à la COVID-19 affecte les populations } \\
\text { socialement vulnérables et les personnes souffrant de comorbidité chronique pendant et après la } \\
\text { - Rechémie de COVID-19 } \\
\text { - Pontribué à la réaction des systèmes de santé, aux résultats et aux conséquences non intentionnelles } \\
\text { - Plans de recherche et de diffusion des résultats }\end{array}$ \\
\hline $\begin{array}{l}\text { Patient-Centered Outcomes } \\
\text { Research Institute (PCORI } \\
\text { 2020) }\end{array}$ & $\begin{array}{l}\text { Les possibilités de financement de l'institut PCORI concernent les trois secteurs prioritaires suivants : } \\
\text { - Adaptation de la prestation des soins } \\
\text { - Impact de la COVID-19 sur les populations vulnérables } \\
\text { - Impact de la COVID-19 sur le bien-être, la gestion et la formation du personnel de santé }\end{array}$ \\
\hline $\begin{array}{l}\text { National Institutes of Health } \\
(\mathrm{NIH} 2020)\end{array}$ & 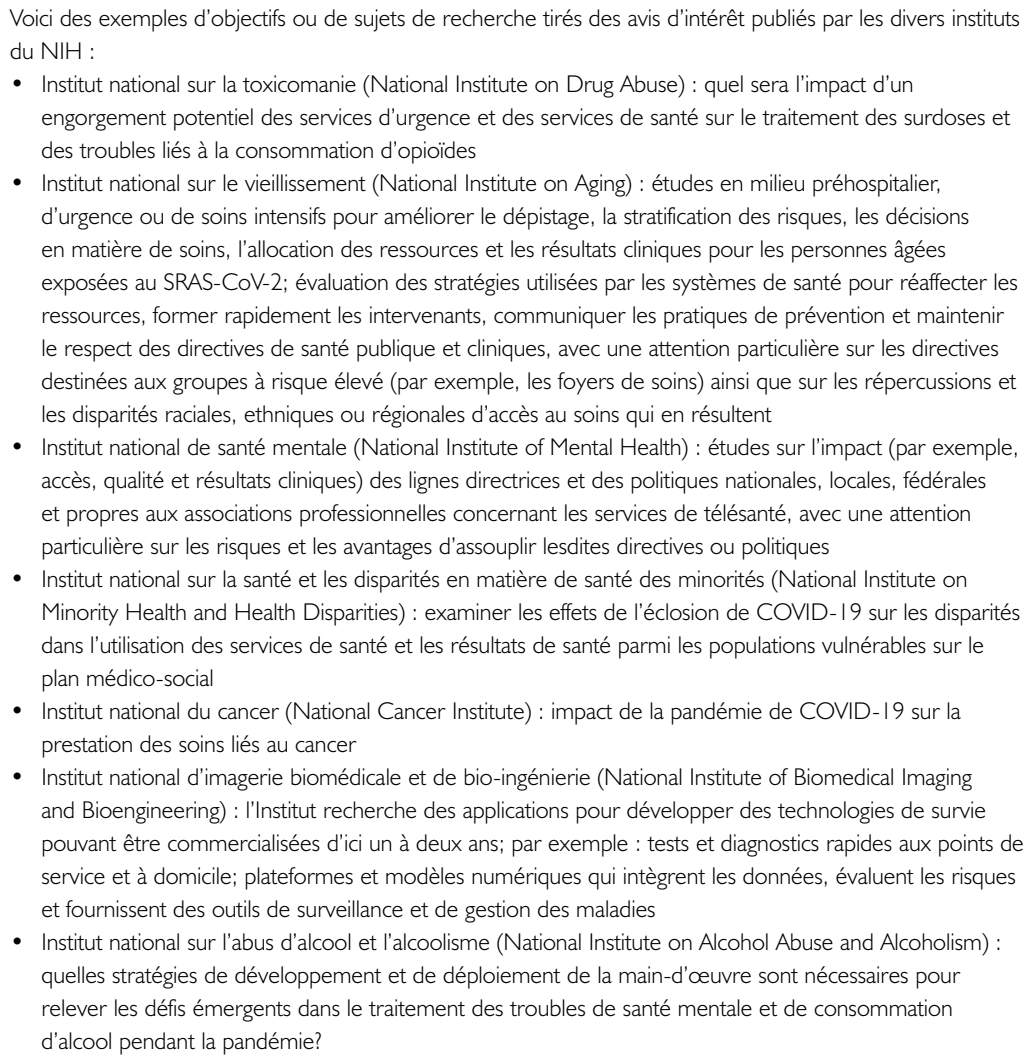 \\
\hline
\end{tabular}

*Cette liste n'est pas exhaustive, il s'agit d'un aperçu. 


\title{
Éclairer la réponse du système de santé canadien à la COVID-19 : priorités pour la recherche sur les services et les politiques de santé
}

\author{
MEGHAN MCMAHON, JESSICA NADIGEL, ERIN THOMPSON ET RICHARD H. GLAZIER
}

ANNEXE 1. méthode employée pour le processus d'identification rapide des priorités

\begin{abstract}
Analyse rapide de la documentation mise à jour en continu
Une analyse rapide a été réalisée à la fin mars, et mise à jour à la fin avril, afin d’identifier l'éventail des questions et thèmes de recherche sur les services et les politiques de santé (RSPS) liée à la COVID-19 qui émergent dans la littérature évaluée par les pairs. Les bases de données MEDLINE et Cochrane ont été consultées conjointement avec les sites Web du choix de revues suivantes : JAMC, New England Journal of Medicine, BMJ, BMC Health Services Research et The Lancet. La recherche portait sur deux concepts principaux : la COVID-19 (et ses variantes terminologiques) et la RSPS (et des variantes comprenant la recherche sur les services de santé, la recherche sur les politiques de santé et la recherche en santé). Les titres, les résumés et le texte intégral ont été examinés pour déterminer la pertinence en matière de RSPS liée à la COVID-19.
\end{abstract}

\section{Revue des médias}

Une revue rapide des principales sources d'information nationales a été réalisée à la fin mars et de nouveau à la mi-avril pour identifier la nature et l'ampleur de la couverture des services de santé et des problèmes liés aux politiques concernant la COVID-19. Les sites Web et articles du Globe and Mail, du National Post, de la CBC et de CTV, rédigés par les principaux journalistes canadiens de la santé, ont ainsi été analysés.

\section{Contribution d'experts en RSPS}

Un échantillon d'experts en RSPS représentant divers secteurs a été consulté pour obtenir un aperçu des priorités en matière de RSPS liée à la COVID-19. L'échantillon de commodité comprenait les membres du conseil consultatif de l'ISPS des IRSC $(n=14)$ (https://cihr-irsc.gc.ca/f/50749.html), d'éminents chercheurs et décideurs en politiques des services de santé $(n=13)$ et des dirigeants d'organismes provinciaux de financement de la recherche en santé au Canada $(n=9)$. La demande initiale comportait une question ouverte sur leur point de vue quant aux principales priorités en matière d'investissement et d'intérêt 
pour la recherche. Les répondants ont ensuite reçu une liste préliminaire des priorités émergentes qu'ils ont commentées et affinées. Le conseil consultatif de l'ISPS s'est réuni à deux reprises (mi-avril et début mai) pour s'entretenir au sujet de ces priorités.

\section{Enquête auprès du milieu de la RSPS}

Une brève enquête a été envoyée au milieu de la RSPS. L'enquête portait sur deux questions fondamentales : quelles sont les priorités les plus importantes pour la RSPS liée à la COVID-19 et comment votre recherche a-t-elle été affectée par la COVID-19? Les questions permettaient une combinaison de réponses à choix multiple structurées et de réponses ouvertes. Le sondage a été distribué par l'entremise de la liste de diffusion de l'ISPS des IRSC et a fait l'objet d'un rappel sur Twitter. En tout, 235 réponses ont été reçues et analysées. Le présent document incorpore les résultats obtenus pour la question sur les priorités de recherche. 